\title{
Differential absorbance as evaluation method of TOX concentrations generated during surface water chlorination
}

\author{
Andrzej Jodłowski ${ }^{1, *}$ \\ ${ }^{1}$ Lodz University of Technology, Institute of Environmental Engineering and Building Installations, \\ 90-924 Lodz, Politechniki Ave 6, Poland
}

\begin{abstract}
Chlorination of waters containing natural organic matter (NOM) produces disinfection byproducts (DBPs) including harmful THMs and HAAs. A collective parameter and toxicity index of all chlorination products contained in finished water is the total concentration of organic-bound halogen compounds (TOX). Determination of this indicator is carried out by adsorption-pyrolysis method, which is complicated and requires specialized apparatus. The competitive method of TOX concentration determination in water is differential absorbance. Effect of natural organic matter removal from surface waters in coagulation as well in coagulation and adsorption processes on the decrease of TOX concentration measured by differential absorbance was determined.
\end{abstract}

\section{Introduction}

The basic purpose of chlorination of water intended for consumption is disinfection, i.e. the destruction of pathogenic organisms. If the water contains organic compounds, chlorine reacts with them, leading to their chlorination and oxidation. Singer and Chang [1] reported that as a result of chlorination of surface waters treated by conventional coagulation, sedimentation and filtration at neutral $\mathrm{pH}$, the THM share of the total number of DBPs formed as TOX after a reaction time of $72 \mathrm{~h}$ is only $26 \%$. The ratio of TOX to THM ranges from 3 to 10 , depending on the quality of the raw water and the conditions of purification [2].

In order to reduce the potential for DBPs formation, it is usual to use NOM removal prior to water chlorination using coagulation and flocculation followed by sedimentation (or flotation) and filtration. However, it should be keep in mind that the more sensitive to the removal in the coagulation process are high molecular weight NOM components than low molecular weight hydrophilic compounds. Remaining in treated water, they are the precursors of DBPs. The parameter for evaluating the susceptibility of NMO components to coagulation removal is SUVA (Specific UV Absorbance) calculated as $\mathrm{UV}_{254}\left(\mathrm{~m}^{-1}\right)$ normalized to DOC $\left(\mathrm{g} \mathrm{C}^{3} \mathrm{~m}^{3}\right)$ [3]. If water is characterized by a SUVA value of approximately $2 \mathrm{~L} /(\mathrm{mg} \mathrm{C} \times \mathrm{m})$, it means that it contains low molecular weight of non-humic substances and hydrophilic properties. In this situation, powdered activated carbon (PAC) can be used to intensify the removal of NMO-containing substances by coagulation [4].

The method used for the TOX assay presented in Standard Methods [5] (method 5320) includes adsorption, pyrolysis and titration. This method was used for instance by Archer and Singer [6] in the study of the role of SUVA and inhanced coagulation in the removal of TOX precursors. This method is quite cumbersome and requires the involvement of advanced measuring equipment.

Another approach to TOX was proposed by Korshin et al. [7]. Based on the spectrophotometric analysis of DBPs precursors compounds, they suggested the possibility of using the method of estimating the concentration of total halogenated organic compounds (TOX) in the method of differential absorbance. Contrary to the conventional NOM absorption spectra before and after chlorination, UV diffraction spectra have almost always a peak near $272 \mathrm{~nm}$. The TOX method requires a spectrophotometer with a measuring range in UV and by measuring the absorbance at $272 \mathrm{~nm}$ before and after the chlorination process under standard conditions, the value of $\Delta \mathrm{A}_{272}$ is calculated, and then using the simple relationships, the total concentration of the resulting chloroorganic compounds, TOX, can be estimated.

It was found that the value of $\Delta \mathrm{A}_{272}$ is linearly correlated with the concentration of TOX in a sample of chlorinated water:

$$
T O X_{\text {powstate }}=k \Delta A_{272}
$$

Korshin et al. [8] determined from a series of studies the correlation between the value of $A_{272}$ and the TOX concentration determining that the value of the coefficient factor $k$ is $10800(\mu \mathrm{g} \times \mathrm{cm}) / \mathrm{L}$. It has been suggested that the use of the $\Delta A_{272}$ measurement is an excellent indicator of the formation of general halogenated organic compounds (TOX), independent of chlorine to dissolved organic carbon (RWO) ratio, bromide concentration, $\mathrm{pH}$, reaction time and $\mathrm{NOM}$ origin.

Corresponding author: andrzej.jodlowski@p.lodz.pl 
The purpose of the study was to determine the effect of removal of natural organic admixtures from surface waters in coagulation and in comparison coagulation and adsorption processes using PAC to reduce the TOX concentration resulting from chlorination and determined by differential absorbance.

\section{Materials and methods}

\subsection{Water used during the study}

The study was conducted using tap water contaminated with humus extract and using natural water taken from the Pilica River. Humus extract was prepared from garden peat, whose aqueous suspension was basified with sodium hydroxide to a $\mathrm{pH}$ of 10.0 , and then filtered twice through a paper filter. The extract was added to tap water in the amount of $5 \mathrm{~mL} / \mathrm{L}$. Water from the Pilica River was collected during the flood from the chambers of intake of the water treatment plant (WTP) "Tomaszów". The results of the analysis of raw water prepared in the laboratory and the water from the Pilica River are presented in Table 1.

Table 1. Characteristics of waters used during the study.

\begin{tabular}{|c|c|c|}
\hline Parameter & $\begin{array}{c}\text { Tap water } \\
\text { contaminated } \\
\text { with humic } \\
\text { extract } \\
\end{array}$ & $\begin{array}{c}\text { Water from } \\
\text { Pilica River } \\
\text { (filtrated } \\
\text { sample) } \\
\end{array}$ \\
\hline Color, g Pt $/ \mathrm{m}^{3}$ & $117-154$ & $176-198$ \\
\hline Turbidity, NTU & $0.43-1,23$ & $3.1-3.9$ \\
\hline Temperature, ${ }^{\circ} \mathrm{C}$ & $20.0-22,5$ & $17.0-17.5$ \\
\hline $\mathrm{pH},-$ & $7.45-8.45$ & $7.64-7.69$ \\
\hline $\begin{array}{l}\text { Alkalinity, g } \\
\mathrm{CaCO}_{3} / \mathrm{m}^{3}\end{array}$ & 175 & $80-90$ \\
\hline DOC, $\mathrm{g} \mathrm{C} / \mathrm{m}^{3}$ & $7.39-10.58$ & $21.7-25.3$ \\
\hline Absorbance $\mathrm{UV}_{254}, \mathrm{~m}^{-}$ & $22.9-30.1$ & $66.4-79.3$ \\
\hline$\underset{1}{\text { Absorbance } \mathrm{UV}_{272}, \mathrm{~m}^{-}}$ & $23.4-28.0$ & $50.4-65.0$ \\
\hline SUVA, $\mathrm{m}^{3} /(\mathrm{g} \mathrm{C} \times \mathrm{m})$ & $2.38-4.07$ & $3.06-3.13$ \\
\hline
\end{tabular}

\subsection{Research on water purification}

Standardized jar test procedure was used in the water purification studies. Coagulation was carried out with aluminum sulfate $\left(\mathrm{Al}_{2}\left(\mathrm{SO}_{4}\right)_{3} \times 18 \mathrm{H}_{2} \mathrm{O}\right)$, which was dosed as $1 \%$ solution. The $\mathrm{pH}$ was adjusted during tests to the value 6.0. Rapid mixing time was about 3 minutes, slow mixing was carried out for 15 minutes, and sedimentation time was set for 30 minutes. Some of the experiments were carried out with the addition of powdered activated carbon (PAC) CWZ-22 type. According to the manufacturer, this PAC has a specific surface area of $800-950 \mathrm{~m}^{2} / \mathrm{g}$, and the pore volume is between 1.5 and $2.0 \mathrm{~cm}^{3} / \mathrm{g}$. PAC was added as an aqueous slurry during rapid mixing. Water quality was measured in raw water, water purified during coagulation and water after coagulation/adsorption after filtration through Munktell paper filter. Water, $\mathrm{pH}$, color, DOC and absorption at $254 \mathrm{~nm}$ and $272 \mathrm{~nm}$ were measured in water under the investigation.

Chlorination of raw and purified water was carried out with a $1.25 \mathrm{mg} \mathrm{Cl}_{2} / \mathrm{L}$ sodium hypochlorite solution after adjusting the $\mathrm{pH}$ value of 8.0. The mass ratio $\mathrm{Cl}_{2}$ : $\mathrm{DOC}=1: 1$ was preserved. Absorbance at $272 \mathrm{~nm}$ was determined in water before chlorination and in chlorinated water and then the difference in these values $\left(\Delta \mathrm{A}_{272}\right)$.

\subsection{Applied analytical procedures}

The water color and absorbance of UV254 and UV272 were determined using the HITACHI UV-VIS U-2001 spectrophotometer during the analytical inspection of water. UV-Spectra software was also used. Turbidity was quantified using a HACH 2100 IS turbidimeter. The CP-505 ELMETRON digital $\mathrm{pH}$ meter was used for $\mathrm{pH}$ measurement. DOC measurements were performed using the HACH-LANGE IL 550 TOC-TN analyzer.

\section{Results and discussion}

Both laboratory and river water were characterized by large content of high molecular weight organic substances with aromatic structure and hydrophobic properties as shown by the SUVA value, which exceeds $3.0 \mathrm{~L} /(\mathrm{mg} \mathrm{C} \times \mathrm{m})$. The content of organic impurities expressed by DOC concentration was significantly higher in river water than in model water prepared on the basis of humus extract. SUVA values were slightly higher for river water (Table 1). The dose of coagulant for effective water purification was under the effect not only by the dissolved organic matter content and chemical nature but also by the turbidity particles, especially in the case of river water.

The effectiveness of organic matter removal as a result of both water types coagulation using aluminum sulphate is shown in Fig. 1. The technological effect of water contaminated with humic extract was obtained with significantly lower doses of coagulant than in the case of river water. It should also be noted that high molecular weight humic substances with double bonds were relatively easily removed, as evidenced by changes in ultraviolet light absorption at $254 \mathrm{~nm}$ (Fig. 1a). It can be concluded that the low molecular weight content that is not absorbed at $254 \mathrm{~nm}$ was relatively small. The course of coagulation of water from the Pilica River showed a more diverse composition of organic matter from the point of view of their fractional composition (Fig. 1b). It can be assumed that the concentration of hydrophilic low molecular weight substances was higher in river water. With regard to both types of water, a high degree of color reduction was obtained as a result of coagulation. For water with humus extract at $120 \mathrm{mg} / \mathrm{L}$ 
aluminum sulphate, the water color was reduced to 21 $\mathrm{mg} \mathrm{Pt} / \mathrm{L}$, and the color of water coming from the Pilica River was reduced to $24 \mathrm{mg} \mathrm{Pt} / \mathrm{L}$ at a coagulant dose of $150 \mathrm{mg} / \mathrm{L}$.
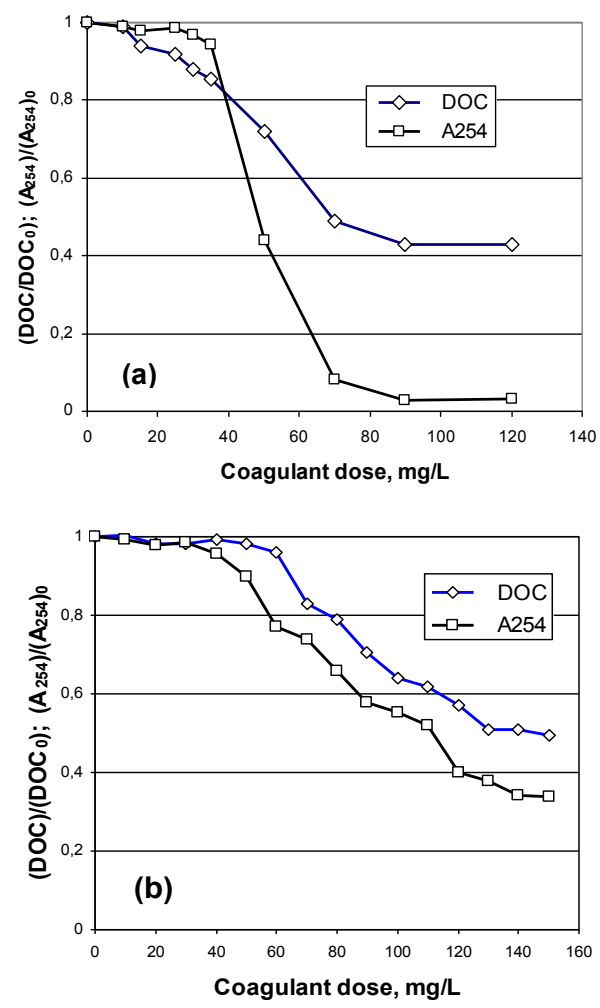

Fig. 1. Changes of DOC concentration and A254 absorption as a result of alum coagulation. a) tap water contaminated with humic substances, b) Pilica River water.

To enhance the removal efficiency of organic matter, especially in the case of low molecular weight fractions of hydrophilic properties, i.e. non-absorbing molecules at $254 \mathrm{~nm}, \mathrm{PAC}$ in the dose of $10 \mathrm{mg} / \mathrm{L}$ was introduced to the purified water in addition to the coagulant. Changes in DOC level and SUVA values resulting from purification of water contaminated with humic extract are presented in Table 2, and changes in the values of the same indicators occurring during purification of water from the Pilica River are presented in Table 3.

Samples of raw and purified water were chlorinated under predefined conditions ( $\mathrm{pH}$ of $8.0, \mathrm{Cl}_{2}: \mathrm{RWO}=1: 1$, contact time $=24 \mathrm{~h}$ ). The concentration of TOX was calculated based on the values of $\Delta \mathrm{A}_{272}$ (Tables 2 and 3 ). It can be seen that the concentration of TOX generated was reduced with decreasing concentration of organic substances expressed by DOC values. Fig. 2 shows the dependence of the TOX concentration generated under the applied chlorination conditions of water versus the DOC concentration. It can be seen that the concentration of TOX generated was reduced according to decreasing concentration of organic substances expressed by DOC values.

The highest values of TOX were found out in the water sample taken from Pilica river during heavy rains. That kind of water was characterized by high DOC level.
Treatment of water contaminated with humic extract as well as water from Pilica river by using aluminum sulfate coagulation, and especially after the introduction of PAC, have reduced the amount of organic matter and consequently reduced the amount of TOX resulting from chlorination.

Table 2. Changes of DOC, SUVA values and TOX concentration as a result of water containing humic substances treatment.

\begin{tabular}{|c|c|c|c|c|}
\hline $\begin{array}{c}\text { Water } \\
\text { treatment }\end{array}$ & $\begin{array}{c}\text { DOC, } \\
\mathbf{m g ~ C / L}\end{array}$ & $\begin{array}{c}\text { SUVA, } \\
\mathbf{L} /(\mathbf{m g} \mathbf{C} \times \mathbf{m})\end{array}$ & $\mathbf{\Delta \mathbf { U V } _ { \mathbf { 2 7 2 } }}$ & $\begin{array}{c}\text { TOX, } \\
\boldsymbol{\mu g} / \mathbf{L}\end{array}$ \\
\hline Raw water & 10.56 & 2.54 & 0.094 & 1015 \\
\hline $\begin{array}{c}\text { Coagulant } \\
\text { dose } \\
\left(50 \mathrm{~g} / \mathrm{m}^{3}\right)\end{array}$ & 6.23 & 1.76 & 0.046 & 497 \\
\hline $\begin{array}{c}\text { Coagulant } \\
\text { dose } \\
\left(70 \mathrm{~g} / \mathrm{m}^{3}\right)\end{array}$ & 5,17 & 1.53 & 0.039 & 421 \\
\hline $\begin{array}{c}\text { Coagulant } \\
\text { dose } \\
(70 \mathrm{mg} / \mathrm{L}), \\
\mathrm{PAC} \mathrm{dose} \\
(10 \mathrm{mg} / \mathrm{L})\end{array}$ & 4.97 & 0.92 & 0.010 & 108 \\
\hline
\end{tabular}

Table 3. Changes of DOC, SUVA values and TOX concentration as a result of Pilica River water treatment.

\begin{tabular}{|c|c|c|c|c|}
\hline $\begin{array}{c}\text { Water } \\
\text { treatment }\end{array}$ & $\begin{array}{c}\text { DOC, } \\
\mathbf{m g} \mathbf{C} / \mathbf{L}\end{array}$ & $\begin{array}{c}\text { SUVA, } \\
\mathbf{L} /(\mathbf{m g} \mathbf{C} \times \mathbf{m})\end{array}$ & $\mathbf{\Delta} \mathbf{U V}_{\mathbf{2 7 2}}$ & $\begin{array}{c}\mathbf{T O X}, \\
\mathbf{\mu g} / \mathbf{L}\end{array}$ \\
\hline Raw water & 21.10 & 2.32 & 0.323 & 3488 \\
\hline $\begin{array}{c}\text { Coagulant } \\
\text { dose } \\
\left(50 \mathrm{~g} / \mathrm{m}^{3}\right)\end{array}$ & 16.82 & 2.05 & 0.145 & 1582 \\
\hline $\begin{array}{c}\text { Coagulant } \\
\text { dose } \\
\left(70 \mathrm{~g} / \mathrm{m}^{3}\right)\end{array}$ & 9.71 & 1.85 & 0.061 & 659 \\
\hline $\begin{array}{c}\text { Coagulant } \\
\text { dose } \\
(70 \mathrm{mg} / \mathrm{L}), \\
\begin{array}{c}\text { PAC dose } \\
(10 \mathrm{mg} / \mathrm{L})\end{array}\end{array}$ & 3.31 & 0.54 & 0.017 & 186 \\
\hline
\end{tabular}

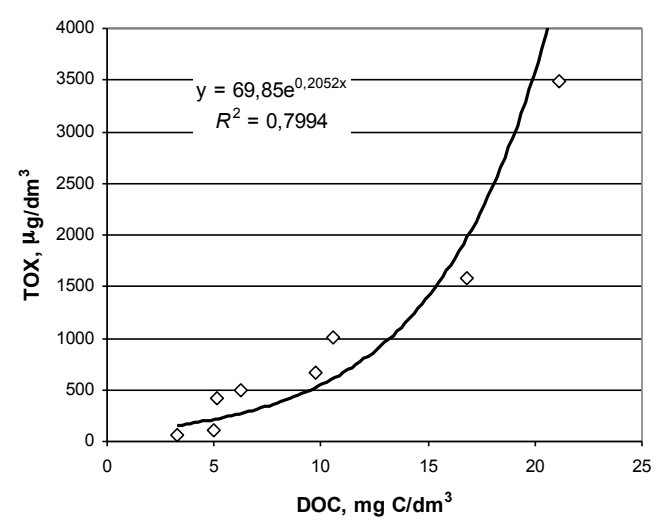

Fig. 2. Formation of total organic halogen (TOX) as a function of dissolved organic carbon (DOC). 
The exponential relationship between the TOX formation potential and the DOC concentration could be also obtained based on the data presented in [6]. It includes, among others, raw water quality data of 27 samples taken at various US water plants. The water samples used in the studies were characterized by determining the alkalinity, TOC, DOC, UV254, SUVA, $\mathrm{pH}$, turbidity and hardness. Chlorination was carried out using sodium hypochlorite under similar conditions as used in this study. The contact time was $24 \mathrm{~h}$, the $\mathrm{pH}$ was 8.0 , the temperature was $20^{\circ} \mathrm{C}$. A slightly different dosage of chlorine was used as it was set so that the residual chlorine concentration was about $1 \mathrm{mg} \mathrm{Cl}_{2} / \mathrm{L}$. The TOX concentration was determined using the method described in Standard Methods [5]. The resulting relationship between the TOX formation potential and the DOC concentration in the raw water used is shown in Fig. 3.

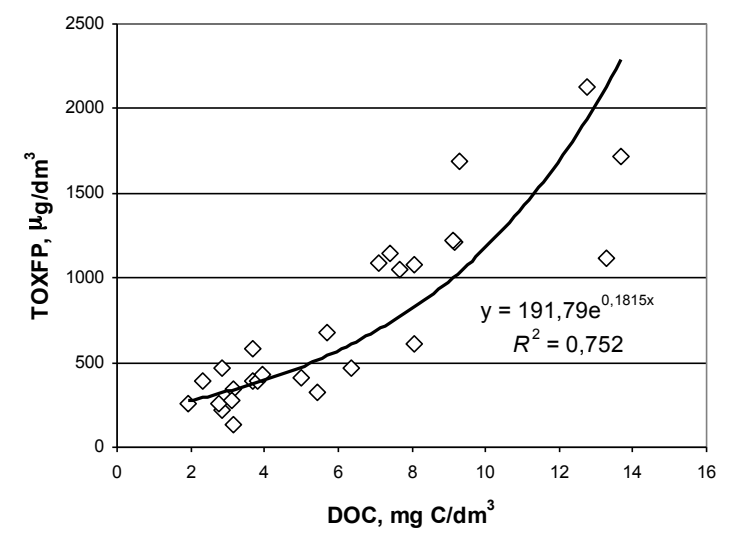

Fig. 3. Relation between TOX formation potential and DOC concentration in raw water from 27 US water treatment plants based on data taken from [6].

Differential absorbance also makes it possible to estimate the concentration of individual organochlorine compounds resulting from NOM chlorination [9].

DBPs concentration depending on $-\Delta \mathrm{A}_{272}$ can almost always be presented in the form of linear equations with values of $R^{2}>0.95$. Korshin et al. [7] found that the only DBPs which did not agree with this trend was $\mathrm{CH}$, which concentration correlated better with $-\Delta \mathrm{A}_{272}$ according to the exponential relationship. TCP and DCAN were unstable at $\mathrm{pH} 7$ and 8 , but at $\mathrm{pH} 6$, the linear relationship between their concentration and $-\Delta \mathrm{A}_{272}$ was as strong as for those more stable DBPs. Dependence of DBPs concentration from $-\Delta \mathrm{A}_{272}$ may be of practical importance as they provide an alternative approach to monitoring the emergence of individual DBP forms in on-line measurements.

Özdemir et al. [10] performed chlorination of raw water samples from Lake Terkos and Lake Büyükçekmece, which are sources of water supply for the city of Istanbul (Turkey). It was found that the spectral characteristics of the chromophore structures absorbed in the UV range by the action of chlorine were obtained. A strong linear correlation was found between $\Delta \mathrm{UV}_{272}$ and TTHM $\left(R^{2}>0.96\right)$. It has been observed that the group of THM compounds formed by the chlorination of raw lake water was dominated by $\mathrm{CHCl}_{3}$.

\section{Conclusions}

1. As a result of coagulation of model water contaminated with humic extract and natural water taken from the Pilica River, the removal rate of dissolved organic substances characterized by DOC was $51 \%$ and $54 \%$, respectively.

2. The use of PAC at the coagulation step has increased the removal of organic matter measured as TOC from water contaminated with humic extract to $53 \%$ and from river water to $84 \%$.

3. Increased efficiency of organic matter removal from water by using coagulation, filtration and adsorption processes made it possible to reduce the TOX concentration by $89 \%$ in the case of tap water contaminated with humic extract and by $95 \%$ in the case of river water.

4. Differential absorbance $\left(\Delta U_{272}\right)$ is an alternative approach to the estimation of TOX and THM concentrations, including chloroform level, formed by the NOM-containing waters.

5. Differential absorbance provides the ability to continuously monitor the concentration of halogenated organics resulting from the chlorination of water containing NOM.

\section{References}

1. P.C. Singer, S.D. Chang, J. AWWA 81, 8 (1989)

2. H. Pourmoghaddas, A.A. Stevens, Wat. Res. 29, 9 (1995)

3. T. Karanfil, M.A. Schlauntman, I. Erdogan, J. AWWA 94, 12 (2002)

4. I.N. Najm, V.L. Snoeyink, B.W. Lykins, J.Q. Adams; J. AWWA 83, 1 (1991)

5. Standard Methods. For The Examination of Water and Wastewater, 20 ${ }^{\text {th }}$ ed. (APHA, AWWA, WEF. Washington DC, 1998)

6. A.D. Archer, P.S. Singer, J. AWWA 98, 8 (2006)

7. G.V. Korshin, M.B. Benjamin, Wat. Res. 31, 4 (1997)

8. G.V. Korshin, M.B. Benjamin, Wat. Res. 31, 7 (1997)

9. G.V. Korshin, M.B. Benjamin, O. Hemingway, W. $\mathrm{Wu}$, Development of differential UV spectroscopy for DBP monitoring (AWWA Research Foundation; American Water Works Association, 2002)

10. K. Özdemir, I. Toröz, V. Uyak, TSWJ. Article ID 890854 (2013) 